\title{
A comparative genomics screen identifies a Sinorhizobium meliloti 1021 sodM-like gene strongly expressed within host plant nodules
}

Clothilde Queiroux ${ }^{1}$, Brian K Washburn ${ }^{1}$, Olivia M Davis ${ }^{1,2 \dagger}$, Jamie Stewart ${ }^{1 \dagger}$, Tess E Brewer ${ }^{1}$, Michael R Lyons ${ }^{1,3}$ and Kathryn M Jones ${ }^{1 *}$

\begin{abstract}
Background: We have used the genomic data in the Integrated Microbial Genomes system of the Department of Energy's Joint Genome Institute to make predictions about rhizobial open reading frames that play a role in nodulation of host plants. The genomic data was screened by searching for ORFs conserved in a-proteobacterial rhizobia, but not conserved in closely-related non-nitrogen-fixing a-proteobacteria.

Results: Using this approach, we identified many genes known to be involved in nodulation or nitrogen fixation, as well as several new candidate genes. We knocked out selected new genes and assayed for the presence of nodulation phenotypes and/or nodule-specific expression. One of these genes, SMc00911, is strongly expressed by bacterial cells within host plant nodules, but is expressed minimally by free-living bacterial cells. A strain carrying an insertion mutation in SMc00911 is not defective in the symbiosis with host plants, but in contrast to expectations, this mutant strain is able to out-compete the S. meliloti 1021 wild type strain for nodule occupancy in coinoculation experiments. The SMc00911 ORF is predicted to encode a "SodM-like" (superoxide dismutase-like) protein containing a rhodanese sulfurtransferase domain at the N-terminus and a chromate-resistance superfamily domain at the C-terminus. Several other ORFs (SMb20360, SMc01562, SMc01266, SMc03964, and the SMc01424-22 operon) identified in the screen are expressed at a moderate level by bacteria within nodules, but not by free-living bacteria.
\end{abstract}

Conclusions: Based on the analysis of ORFs identified in this study, we conclude that this comparative genomics approach can identify rhizobial genes involved in the nitrogen-fixing symbiosis with host plants, although none of the newly identified genes were found to be essential for this process.

Keywords: Rhizobia, Sinorhizobium meliloti, Alfalfa, Symbiosis, Nitrogen fixation, Bacteria, Legume, Genomics, a-proteobacteria

\section{Background}

Sinorhizobium meliloti 1021 is a soil bacterium that establishes a nitrogen-fixing symbiosis with the host plants Medicago sativa (alfalfa) and Medicago truncatula (reviewed in [1,2]). These plants are not only agriculturally important, but are also key model organisms for studying the symbiotic interaction between rhizobial

\footnotetext{
* Correspondence: kmjones@bio.fsu.edu

${ }^{\dagger}$ Equal contributors

'Department of Biological Science, Florida State University, Biology Unit I,

230A, 89 Chieftain Way, Tallahassee, FL 32306-4370, USA

Full list of author information is available at the end of the article
}

bacteria and their plant hosts. The goals of this study are to increase our understanding of this process and provide practical insights that may lead to the production of more efficient symbiotic strains of rhizobia. Increasing the efficiency of symbiotic nitrogen fixation is important in that it reduces the need for industrial production of nitrogen fertilizers, which is extremely costly in terms of petroleum and natural gas. In 2007, the US applied 13 million tons of industrially-produced nitrogen fertilizer to crops [3]. Fertilizers continue to be used to increase yields of legume crops [3], demonstrating that there is considerable room for improvement in these symbiotic associations.

\section{Ciomed Central}

(c) 2012 Queiroux et al.; licensee BioMed Central Ltd. This is an Open Access article distributed under the terms of the Creative Commons Attribution License (http://creativecommons.org/licenses/by/2.0), which permits unrestricted use, distribution, and reproduction in any medium, provided the original work is properly cited. 
S. meliloti fixes nitrogen in root nodules formed by the host plant, converting dinitrogen gas to ammonia. The development of these nodules requires that several signals be exchanged between the plant and the rhizobial bacteria. Flavonoid compounds produced by host plants signal S. meliloti to produce lipochitooligosaccharides called Nod factors (NFs) [4]. NF activates multiple responses in host plants, including tight curling of root hairs that traps bacterial cells within the curl, and cell divisions in the root cortex, which establish the nodule primordium $[5,6]$. The bacteria invade and colonize the roots through structures called infection threads, which originate from microcolonies of bacteria trapped in the curled root hair cells $[1,7]$. New infection threads initiate at each cell layer, eventually delivering the bacteria to the inner plant cortex [7]. There, the rhizobial bacteria are endocytosed by root cortical cells within individual compartments of host-cell membrane origin $[2,8]$. Within these compartments, signals provided by the plant and the low-oxygen environment induce the bacteria to differentiate into a form called a "bacteroid", and to begin expressing nitrogenase, the nitrogen-fixing enzyme, and other factors that are required for the symbiosis $[9,10]$.

Rhizobial fixation of dinitrogen requires not only the expression of nitrogenase (encoded by the genes nifK and nifD [11]), but also the assembly of cofactors and large inputs of energy and reductant [12]. Nitrogen fixation also requires a nitrogenase reductase, encoded by nifH [11]; iron-molybdenum cofactor biosynthesis proteins, encoded by nifB, nifE and nifE; and electron transfer flavoproteins and ferredoxins (fixA, fixB, fix $C, f i x X$ ) [13-16]. Bacteroids also increase their respiration rate, increasing the expression of the fixNOQP cytochrome c oxidase operons [17-20].

Many of the proteins required for nitrogen fixation are tightly regulated by oxygen-sensing systems and are produced by rhizobial bacteria only when they encounter a low-oxygen environment [21]. Nitrogenase and some of the other factors involved in nitrogen fixation are extremely oxygen-sensitive [22], thus their expression under inappropriate conditions would be ineffective. Even under microaerobic conditions, most rhizobial bacteria are not capable of nitrogen fixation in the freeliving state [23]. The reasons for this are not completely understood, though it is known that legumes of the inverted repeat-lacking clade (IRLC), such as alfalfa and M. truncatula, which form indeterminate-type nodules, impose a specific differentiation program on the intracellular bacteria, most likely through the activity of plant-produced bioactive peptides [9,24]. Bacteroids also receive nutrients from the host plant, such as the carbon source malate [25-27]. Multiple bacterial cellular processes and differentiation programs contribute to the success of the symbiosis with host plants, and one of our goals is to use comparative genomics to predict previously uncharacterized $S$. meliloti open reading frames (ORFs) that may be involved in these processes, to test these predictions, and understand the mechanisms involved. In other bacterial species, comparative genomics of bacterial strains has been useful in finding new genes that are involved in metabolic pathways and in identifying virulence factors that distinguish pathogenic strains from commensal strains (examples include: $[28,29])$. In this study, a comparison of ORFS from nitrogen-fixing, plant-host nodulating rhizobia with closelyrelated non-nitrogen-fixing bacteria has identified ORFs that are expressed by Sinorhizobium meliloti within host plant nodules.

\section{Methods}

\section{Genome comparisons}

Searches were conducted at the Department of Energy Joint Genome Institute's Integrated Microbial Genomes website, http://img.jgi.doe.gov/cgi-bin/pub/main.cgi. All of the genomes to be compared were selected from the genome display under the "Find Genomes" tab (see Table 1 for compared genomes). The selected genomes were saved. The "Phylogenetic profiler" for single genes was used to find genes in Sinorhizobium/Ensifer meliloti with homologs in the genomes to be intersected and without homologs in the genomes to be subtracted (see Table 1). The searches were conducted at $20-80 \%$ identity and the complete data output is listed in Additional file 1: Table S1.

\section{Bacterial strains and growth conditions}

S. meliloti 1021 strains were grown at $30^{\circ} \mathrm{C}$ in either LBMC (Luria Bertani [Miller] medium supplemented with $2.5 \mathrm{mM} \mathrm{MgSO}_{4}$ and $2.5 \mathrm{mM} \mathrm{CaCl}_{2}$ ), or $1 / 10 \mathrm{LB}$ $7 \%$ sucrose medium, with $1 \mathrm{mM} \mathrm{MgSO}_{4}$ and $0.25 \mathrm{mM}$ $\mathrm{CaCl}_{2}$, or M9 salts-10\% sucrose medium, supplemented with $1 \mu \mathrm{g} / \mathrm{mL}$ biotin [40]. Bacterial plates contained $1.5 \%$ BactoAgar. Selections against strains carrying the $s a c B$ gene in the plasmid pK19mobsac were performed in M9 supplemented with $10 \% \mathrm{w} / \mathrm{v}$ sucrose or $1 / 10 \mathrm{LB}$ $7 \%$ sucrose [41]. Appropriate antibiotics were used at the following concentrations for $S$. meliloti strains: streptomycin 500 or $1000 \mu \mathrm{g} / \mathrm{mL}$; neomycin $200 \mu \mathrm{g} / \mathrm{mL}$. E. coli strains were grown at $37^{\circ} \mathrm{C}$ in $\mathrm{LB}$ medium [40], with appropriate antibiotics used at the following concentrations: kanamycin $50 \mu \mathrm{g} / \mathrm{mL}$; chloramphenicol $10 \mu \mathrm{g} / \mathrm{mL}$.

\section{Construction of S. meliloti mutant strains}

Mutant strains of S. meliloti 1021 with disruptions in ORFs described in Table 2 were constructed by amplifying internal ORF fragments using Phusion polymerase 
Table 1 Genome ORFs compared with S. meliloti 1021

\begin{tabular}{|c|c|c|}
\hline Genome & Subtracted or intersected & Lifestyle \\
\hline Agrobacterium tumefaciens C58 (Cereon) [30,31] & subtracted & plant pathogen \\
\hline Agrobacterium tumefaciens C58 (Dupont) [30,31] & subtracted & plant pathogen \\
\hline Bartonella bacilliformis KC583 & subtracted & mammalian pathogen \\
\hline Bartonella henselae Houston-1 & subtracted & mammalian pathogen \\
\hline Bartonella quintana Toulouse & subtracted & mammalian pathogen \\
\hline Bartonella tribocorum CIP 105476 & subtracted & mammalian pathogen \\
\hline Brucella abortus bv $19-941$ & subtracted & mammalian pathogen \\
\hline Brucella canis ATCC 23365 & subtracted & mammalian pathogen \\
\hline Brucella melitensis $16 \mathrm{M}$ & subtracted & mammalian pathogen \\
\hline Brucella melitensis bv Abortus 2308 & subtracted & mammalian pathogen \\
\hline Brucella ovis ATCC 25840 & subtracted & mammalian pathogen \\
\hline Brucella suis ATCC 23445 & subtracted & mammalian pathogen \\
\hline Brucella suis 1330 & subtracted & mammalian pathogen \\
\hline Caulobacter crescentus CB15 [32] & subtracted & free-living \\
\hline Caulobacter sp. K31 [33,34] & subtracted & free-living \\
\hline Bradyrhizobium japonicum USDA 110 [35] & intersected & nitrogen-fixing plant symbiont \\
\hline Mesorhizobium loti MAFF303099 [36] & intersected & nitrogen-fixing plant symbiont \\
\hline Rhizobium etli CFN 42 [37] & intersected & nitrogen-fixing plant symbiont \\
\hline Rhizobium leguminosarum bv. viciae 3841 [38] & intersected & nitrogen-fixing plant symbiont \\
\hline Sinorhizobium medicae WSM419 [39] & intersected & nitrogen-fixing plant symbiont \\
\hline
\end{tabular}

(New England Biolabs, Ipswich, MA, USA) and cloning into the plasmid pJH104, which carries a neomycin/ kanamycin resistance marker (Jeanne Harris, Univ. Vermont, personal communication) [42]. Insertion of the pJH104 plasmid also creates transcriptional fusions to the uidA $\beta$-glucuronidase (GUS) gene. Non-disrupting GUS insertions of some ORFs (described in Table 2) were constructed by amplifying the entire ORF or operon and cloning the product into pJH104, and conjugating into S. meliloti. Deletion mutant strains were constructed by amplifying fragments flanking the ORF to be deleted and cloning the fragments into the $s a c B$ gene-containing suicide vector pK19mobsac [41]. (Some fragments were initially cloned into pCR-Blunt II-TOPO using the Zero-TOPO-Blunt cloning kit [Invitrogen, San Diego, CA, USA].) Mutant strains are listed in Table 2. Primers (Eurofins MWG Operon, Huntsville, AL, USA) and restriction enzymes (New England Biolabs, Ipswich, MA, USA) used for amplification and cloning of disruption, non-disrupting insertion, or deletion fragments are listed in Additional file 2: Table S2. Plasmids were mobilized into $S$. meliloti by triparental conjugation as described previously [43]. S. meliloti exconjugants were selected on LBMC medium containing $200 \mu \mathrm{g} / \mathrm{mL}$ neomycin and $1000 \mu \mathrm{g} / \mathrm{mL}$ streptomycin. Unmarked deletion strains were selected for loss of the $s a c B$ gene carried by the pK19mobsac vector by plating neomycin- resistant exconjugants to either M9 salts-10\% sucrose medium or $1 / 10$ LB-7\% sucrose medium. Strains constructed by phage $\phi M 12$ transduction of plasmid insertions into S. meliloti 1021 are denoted in the Tables as "Xsd". Transductions using phage $\phi M 12$ were performed according to published protocols [44]. For each mutant produced, at least two strains were isolated. For some of the mutants, including those which carry an unmarked ORF deletion, multiple independent isolates were obtained by selecting exconjugants from multiple independent conjugations. For most of the mutants carrying an insertion of the $\mathrm{pJH} 104$ plasmid, the independent isolates were the original isolate and strains constructed by transduction of the neomycin-resistance marker into wild type S. meliloti 1021 via phage фM12 [44].

\section{Plant nodulation assays}

The host plant Medicago sativa (alfalfa) cv. Iroquois was prepared for inoculation with $S$. meliloti as in Leigh et al. (1985) with modifications: seeds were sterilized for 5 minutes in $50 \%$ bleach, rinsed in sterile water, and germinated for 3 days on $1 \% \mathrm{w} / \mathrm{v}$ plant cell culturetested agar/water (Sigma, St. Louis, MO, USA) [45]. Seedlings were then moved to individual $100 \mathrm{~mm} \mathrm{x}$ $15 \mathrm{~mm}$ Jensen's medium plates [46], and inoculated with $100 \mu \mathrm{L}$ of $\mathrm{OD}_{600}=0.05 \mathrm{~S}$. meliloti of the appropriate strain. Plants were grown in a Percival AR-36 L 
Table 2 S. meliloti 1021-derived mutant strains

\begin{tabular}{|c|c|c|c|c|}
\hline ORF & Predicted function & $\begin{array}{l}\text { Length } \\
\text { (amino acids) }\end{array}$ & Type of mutation & Strain name \\
\hline \multirow[t]{3}{*}{ SMc01562 } & hypothetical protein & 96 & deletion & $\Delta \mathrm{SMC01562.6}$ \\
\hline & & & & $\Delta S M C 01562.25$ \\
\hline & & & & $\Delta \mathrm{SMC01562.100}$ \\
\hline \multirow[t]{5}{*}{ SMc01562 } & hypothetical protein & 96 & $\begin{array}{l}\text { non-disrupting insertion of } \\
\text { pJH104 GUS marker }\end{array}$ & A104U.original \\
\hline & & & & A104U.Xsd1 \\
\hline & & & & A104U.Xsd6 \\
\hline & & & & A104U.Xsd25 \\
\hline & & & & A104U.Xs100 \\
\hline \multirow[t]{4}{*}{ SMc01986 } & hypothetical protein & 119 & deletion & $\Delta \mathrm{SMC} 01986.1$ \\
\hline & & & & $\Delta \mathrm{SMC01986.6}$ \\
\hline & & & & $\Delta S M c 01986.25$ \\
\hline & & & & $\Delta \mathrm{SMC} 01986.100$ \\
\hline \multirow[t]{3}{*}{ SMc01986 } & hypothetical protein & 119 & $\begin{array}{l}\text { non-disrupting insertion of } \\
\text { pJH104 GUS marker }\end{array}$ & C104.1A.Xsd1 \\
\hline & & & & C104.1A.original \\
\hline & & & & C104.2B.Xsd100 \\
\hline \multirow[t]{2}{*}{ SMc00135 } & hypothetical protein & 243 & deletion & $\Delta \mathrm{SMc00135.B1}$ \\
\hline & & & & $\Delta \mathrm{SMC00135.B17}$ \\
\hline \multirow[t]{3}{*}{ SMc00135 } & hypothetical protein & 243 & $\begin{array}{l}\text { non-disrupting insertion of } \\
\text { pJH104 GUS marker }\end{array}$ & B104.3A \\
\hline & & & & B104.4B \\
\hline & & & & B104.2 C \\
\hline SMc01422 & $\begin{array}{l}\text { hypothetical protein } \\
\text { (probable operon with } \\
\text { SMc01423,SMc01424) }\end{array}$ & 128 & $\begin{array}{l}\text { deletion (SMc01422, SMc01423, } \\
\text { SMc01424 all deleted in this strain) }\end{array}$ & $\begin{array}{l}\Delta S M C 01422-24 . D 21 \\
\Delta S M c 01422-24 . D 29\end{array}$ \\
\hline SMc01423 & $\begin{array}{l}\text { probable nitrile hydratase } \\
\text { subunit } \beta\end{array}$ & 219 & deletion & same as above \\
\hline SMc01424 & $\begin{array}{l}\text { probable nitrile hydratase } \\
\text { subunit a }\end{array}$ & 213 & deletion & same as above \\
\hline \multirow[t]{3}{*}{ SMc01424-01422 } & $\begin{array}{l}\text { hypothetical protein (probable } \\
\text { operon with SMc01423,SMc01422) }\end{array}$ & 213 & $\begin{array}{l}\text { non-disrupting insertion of } \\
\text { pJH104 GUS marker }\end{array}$ & D104.2A \\
\hline & & & & D104.3B \\
\hline & & & & D104.1 C \\
\hline \multirow[t]{3}{*}{ SMa0044 } & hypothetical protein & 89 & deletion & $\Delta \mathrm{SMa0044.c1}$ \\
\hline & & & & $\Delta \mathrm{SMa0044.c6}$ \\
\hline & & & & $\Delta \mathrm{SMa0044.c10}$ \\
\hline \multirow[t]{3}{*}{ SMa0044 } & $\begin{array}{l}\text { non-disrupting insertion of } \\
\text { pJH104 GUS marker }\end{array}$ & 89 & & SMa0044.104.1A \\
\hline & & & & SMa0044.104.1B \\
\hline & & & & SMa0044.104.4 C \\
\hline \multirow[t]{2}{*}{ SMb20431 } & $\begin{array}{l}\text { hypoth. arylmalonate } \\
\text { decarboxylase }\end{array}$ & 261 & $\begin{array}{l}\text { ORF-disrupting insertion of } \\
\text { pJH104 GUS marker }\end{array}$ & SMb20431.original \\
\hline & & & & SMb20431.Xsd1 \\
\hline \multirow[t]{2}{*}{ SMb20360 } & hypothetical protein & 243 & $\begin{array}{l}\text { ORF-disrupting insertion of } \\
\text { pJH104 GUS marker }\end{array}$ & SMb20360.original \\
\hline & & & & SMb20360.Xsd1 \\
\hline
\end{tabular}


Table 2 S. meliloti 1021-derived mutant strains (Continued)

\begin{tabular}{|c|c|c|c|c|}
\hline \multirow[t]{2}{*}{ SMc03964 } & hypothetical protein & 300 & $\begin{array}{l}\text { ORF-disrupting insertion of } \\
\text { pJH104 GUS marker }\end{array}$ & SMc03964.original \\
\hline & & & & SMc03964.Xsd6 \\
\hline \multirow[t]{3}{*}{ SMc00911 } & hypothetical protein & 275 & $\begin{array}{l}\text { ORF-disrupting insertion of } \\
\text { pJH104 GUS marker }\end{array}$ & SMc00911.original \\
\hline & & & & SMc00911.Xsd1 \\
\hline & & & & SMc00911.original2 \\
\hline \multirow[t]{2}{*}{ SMa1334 } & hypothetical protein & 398 & $\begin{array}{l}\text { ORF-disrupting insertion of } \\
\text { pJH104 GUS marker (may have a } \\
\text { polar effect on 3' genes } \\
\text { Sma1332,-1331,-1329) }\end{array}$ & SMa1334.original \\
\hline & & & & SMa1334.Xsd1 \\
\hline \multirow[t]{2}{*}{ SMc01266 } & hypothetical protein & 438 & $\begin{array}{l}\text { ORF-disrupting insertion of pJH104 } \\
\text { GUS marker (may have a polar } \\
\text { effect on 3' gene Smc01265) }\end{array}$ & SMc01266.original \\
\hline & & & & SMc01266.Xsd1 \\
\hline greA & transcription elongation factor & 158 & $\begin{array}{l}\text { ORF-disrupting insertion of } \\
\text { pJH104 GUS marker }\end{array}$ & greA.12.4.1a \\
\hline $\operatorname{expA1}(w g a A)$ & EPSII biosynthesis enzyme & 490 & $\begin{array}{l}\text { ORF-disrupting insertion of Tn5-Nm } \\
\text { in expA-symbiotically proficient, } \\
\text { competitor assay strain }\end{array}$ & expA125::Tn5.Xsd1 \\
\hline
\end{tabular}

incubator (Perry, IA, USA) at $21^{\circ} \mathrm{C}$, with $60-70 \%$ relative humidity, and 100-175 $\mu \mathrm{mol} \mathrm{m} \mathrm{m}^{-2} \mathrm{~s}^{-1}$ light. Plants were measured at 5 weeks and 6.5 weeks of growth. t-tests (unpaired, two-tailed) were performed in Microsoft Excel and in GraphPad (http://www.graphpad.com/ quickcalcs/ttest1.cfm?Format=C).

Nodulation competition assays were performed in the same way as the plant assays described above, except that strains to be tested in competition against one another were prepared as a mixed 1:1 inoculum immediately before inoculation. Bacteria were harvested from nodules after 5 or 6.5 weeks of growth by excising the nodules from roots, surface sterilizing in $20 \%$ bleach for $5 \mathrm{~min}$., washing in sterile, distilled water, and crushing the nodules in $1.5 \mathrm{~mL}$ tubes with a micro-pestle (Kimble-Chase, Vineland, NJ), in $\mathrm{LB}+0.3 \mathrm{M}$ glucose [45]. Dilutions of the material from crushed nodules were plated on $\mathrm{LBMC}+500 \mu \mathrm{g} / \mathrm{mL}$ streptomycin. Colonies were patched from these plates to LBMC $+500 \mu \mathrm{g} /$ $\mathrm{mL}$ streptomycin and $200 \mu \mathrm{g} / \mathrm{mL}$ neomycin to determine the fraction of bacteria that carry the neomycinresistance marker in the insertion plasmid pJH104.

\section{Detection of $\beta$-glucuronidase activity and imaging of root nodules}

$\beta$-glucuronidase expression by bacteria within nodules was detected by excising nodules, surface sterilizing with $20 \%$ bleach for $5 \mathrm{~min}$., rinsing in sterile water, and staining in X-gluc buffer (1 mM 5-bromo-4-chloro-3indolyl-beta-D-glucuronic acid, cyclohexylammonium salt; $0.02 \%$ SDS; $50 \mathrm{mM}$ Na-phosphate, $\mathrm{pH}$ 7) [47] for the amount of time indicated in Table 3. Whole nodules were imaged on an AZ100 Multi-Zoom Microscope equipped with a DS-Fi1, 5 Megapixel color camera (Nikon Instruments U.S., Melville, NY). $\beta$-glucuronidase expression by bacteria on LBMC plates was detected by streaking bacteria to plates that had been spread with $40 \mu \mathrm{L}$ of X-gluc solution (100 mM 5-bromo-4-chloro-3indolyl-beta-D-glucuronic acid, cyclohexylammonium salt solution in dimethylformamide).

\section{Results}

Comparisons of Sinorhizobium meliloti open reading frames with those of other rhizobia and with nonnitrogen fixing a-proteobacteria

Rhizobial functions required for symbiotic nitrogen fixation with legume plants have typically been discovered through the classical bacterial genetic technique of transposon mutagenesis, followed by screening mutants for loss of symbiotic function. We have used an alternative comparative genomics strategy to search for rhizobial genes involved in symbiosis. In this approach, searches of the Joint Genome Institute, Integrated Microbial Genomes (JGI IMG) system [48] were performed to find ORFs that $S$. meliloti 1021 shares with the symbiotic nitrogen-fixing $\alpha$-proteobacteria ( $\alpha$-rhizobia) $S$. medicae WSM419, Rhizobium etli CFN 42, Rhizobium leguminosarum bv. viciae, Mesorhizobium loti MAFF303099, and Bradyrhizobium japonicum USDA110. A novel aspect of this strategy is that these searches were restricted by prior elimination of all $S$. meliloti ORFs that are present in any of 15 non-nitrogen-fixing, non-symbiotic $\alpha$-proteobacteria 
Table 3 Expression of $\boldsymbol{\beta}$-glucuronidase (GUS) fusions

\begin{tabular}{|c|c|c|c|c|c|c|}
\hline ORF & strain & $\begin{array}{l}\text { \% of nodules } \\
\text { with GUS } \\
\text { expression }\end{array}$ & $\begin{array}{l}\text { Strength } \\
\text { of nodule } \\
\text { GUS expression }\end{array}$ & Staining time & $\begin{array}{l}\text { Pattern of nodule } \\
\text { GUS expression }\end{array}$ & $\begin{array}{l}\text { Free-living } \\
\text { GUS } \\
\text { expression }\end{array}$ \\
\hline $\mathrm{N} / \mathrm{A}$ & $\begin{array}{l}\text { S. meliloti } 1021 \text { wild type } \\
\text { (negative control) }\end{array}$ & $0 / 39=0 \%$ & - & variable & none & - \\
\hline \multirow[t]{3}{*}{ SMc00911 } & SMc00911.original & $18 / 20=90 \%$ & ++++ & $1.5-3.75 \mathrm{hr}$ & whole nodule & + \\
\hline & SMc00911.Xsd1 & $18 / 18=100 \%$ & ++++ & $1.5-3.75 \mathrm{hr}$ & whole nodule & n.d. \\
\hline & SMc00911.original2 & n.d. & n.d. & N/A & N/A & + \\
\hline \multirow[t]{2}{*}{ SMb20360 } & SMb20360.original & $8 / 13=62 \%$ & ++ & $3-5 \mathrm{hr}$ & invasion zone-fixation zone & - \\
\hline & SMb20360.Xsd1 & $13 / 16=81 \%$ & ++ & $3-5 \mathrm{hr}$ & invasion zone-fixation zone & - \\
\hline \multirow[t]{3}{*}{ SMc00135 } & B104.3A & $6 / 8=75 \%$ & + & $2-3 \mathrm{hr}$ & invasion zone-interzone & + \\
\hline & B104.4B & $8 / 8=100 \%$ & + & $2-3 \mathrm{hr}$ & invasion zone-interzone & ++ \\
\hline & B104.2 C & $6 / 8=75 \%$ & ++ & $2-3 \mathrm{hr}$ & invasion zone-interzone & ++ \\
\hline \multirow[t]{5}{*}{ SMc01562 } & A104U.original & $7 / 8=88 \%$ & + & $4-6 \mathrm{hr}$ & interzone & - \\
\hline & A104U.Xsd1 & $3 / 7=43 \%$ & $+/-$ & $4-6 \mathrm{hr}$ & interzone-fixation zone & n.d. \\
\hline & A104U.Xsd6 & $8 / 8=100 \%$ & + & $4-6 \mathrm{hr}$ & interzone-fixation zone & n.d. \\
\hline & A104U.Xsd25 & $3 / 8=38 \%$ & $+/-$ & $4-6 \mathrm{hr}$ & interzone-fixation zone & n.d. \\
\hline & A104U.Xs100 & $4 / 9=44 \%$ & + & $4-6 \mathrm{hr}$ & fixation zone & n.d. \\
\hline \multirow[t]{2}{*}{ SMc01266 } & SMc01266.original & $13 / 18=72 \%$ & + & $3 \mathrm{hr}$ & invasion zone-fixation zone & $+/-$ \\
\hline & SMc01266.Xsd1 & $13 / 18=72 \%$ & ++ & $3 \mathrm{hr}$ & invasion zone & - \\
\hline \multirow[t]{2}{*}{ SMc03964 } & SMc03964.original & $8 / 15=53 \%$ & ++ & $3-5 \mathrm{hr}$ & interzone & $+/-$ \\
\hline & SMc03964.Xsd6 & $9 / 19=47 \%$ & ++ & $3-5 \mathrm{hr}$ & interzone-fixation zone & - \\
\hline \multirow[t]{3}{*}{ SMc01424-22 } & D104.2A & $0 / 8=0 \%$ & - & $4-6 \mathrm{hr}$ & N/A & $+/-$ \\
\hline & D104.3B & $7 / 8=88 \%$ & ++ & $4-6 \mathrm{hr}$ & invasion zone-interzone & $+/-$ \\
\hline & D104.1 C & $6 / 8=75 \%$ & + & $4-6 \mathrm{hr}$ & invasion zone-fixation zone & $+/-$ \\
\hline \multirow[t]{3}{*}{ SMa0044 } & SMa0044.104.1A & $4 / 8=50 \%$ & $+/-$ & $6-7 \mathrm{hr}$ & invasion zone-interzone & +++ \\
\hline & SMa0044.104.1B & $4 / 8=50 \%$ & $+/-$ & $6-7 \mathrm{hr}$ & interzone & +++ \\
\hline & SMa0044.104.4 C & $4 / 8 \% 50 \%$ & $+/-$ & $6-7 \mathrm{hr}$ & interzone & +++ \\
\hline \multirow[t]{2}{*}{ SMb20431 } & SMb20431.original & $10 / 16=63 \%$ & + & $5-12 \mathrm{hr}$ & invasion zone-fixation zone & - \\
\hline & SMb20431.Xsd1 & $11 / 15=73 \%$ & + & $5-12 \mathrm{hr}$ & interzone & - \\
\hline \multirow[t]{3}{*}{ SMc01986 } & C104.1A.Xsd1 & $0 / 6=0 \%$ & - & $24 \mathrm{hr}$ & N/A & n.d. \\
\hline & C104.1A.original & n.d. & n.d. & $24 \mathrm{hr}$ & n.d. & $+/-$ \\
\hline & C104.2B.Xsd100 & $2 / 18=11 \%$ & $+/-$ & $24 \mathrm{hr}$ & fixation zone & n.d. \\
\hline \multirow[t]{2}{*}{ SMa1334 } & SMa1334.original & $0 / 11=0 \%$ & - & $5-24 \mathrm{hr}$ & N/A & - \\
\hline & SMa1334.Xsd1 & $0 / 13=0 \%$ & - & $5-24 \mathrm{hr}$ & N/A & - \\
\hline
\end{tabular}

(species listed in Table 1). (See Materials and Methods for search procedure.) The genomes used in the analysis were chosen based on the rhizobial genomes available in the JGI IMG database when the analysis was initially performed. The searches were conducted at multiple identity levels (20\%-80\%), and the output data from all the searches is presented in Additional file 1: Table S1. The genome subtractions eliminated genes common to $\alpha$ proteobacteria with non-symbiotic lifestyles. For example, a search conducted at $50 \%$ identity, intersecting the $S$. meliloti ORFs with homologs in the $5 \alpha$-rhizobia species yields 1281 genes. However, when the search for homologs is conducted with subtraction of the ORFs from the 15 non-rhizobial species, the search yield is 58 genes (Additional file 3: Table S3).

The result of the searches was a list of 139 ORFs common to the $\alpha$-rhizobia (listed in Additional file 3: Table S3), but not found in the non-nitrogen-fixing, nonsymbiotic $\alpha$-proteobacteria. Among these 139 ORFs were 11 genes known to be involved in nitrogen fixation (Table 4 and Additional file 3: Table S3), including: nifH, nifD, nifK, nifB, nifE, nifN, fixA, fixB, and fixC (see 


\begin{tabular}{ll}
$\begin{array}{l}\text { Table } 4 \text { Function distribution of the 139 ORFs from } \\
\text { genome searches (See Additional file 3: Table S3 for } \\
\text { complete gene list) }\end{array}$ & Number of ORFs \\
\hline Function & 11 \\
\hline Nitrogen fixation & 8 \\
Nod factor production/modification & 10 \\
Transposase & 8 \\
Predicted transcriptional regulator & 14 \\
Predicted transport protein & 7 \\
Predicted adenylate/guanylate cyclase & 37 \\
Other predicted function & 44 \\
Hypothetical protein &
\end{tabular}

Introduction) and 8 known to be involved in Nod factor production, including $\operatorname{nod} A, \operatorname{nod} B, \operatorname{nod} C$, nodJ and $\operatorname{nodI}$ [5], thus $13.7 \%(19 / 139)$ of the ORFs selected by this comparative gemonics approach are already known to be important for symbiotic function.

There were also 44 hypothetical proteins/proteins of unknown function among the 139 ORFs detected in the comparative genomic screen. The predicted functions of the remaining ORFs included transposases, transcriptional regulators, transport proteins, and adenylate/guanylate cyclases (Table 4). These are classes of genes that may participate in many of the functions that distinguish $\alpha$-rhizobia from their non-symbiotic $\alpha$-proteobacterial relatives, such as signaling to the host plant, reprogramming their metabolism for nitrogen fixation, and importing specific nutrients and differentiation signals from the plant $[9,10,49]$. Also, atypical adenylate cyclases have been noted before in the rhizobia [50].

\section{Construction and symbiosis assays of mutants in conserved genes}

Thirteen of the 139 conserved ORFs were chosen for further study because they are of undetermined function in S. meliloti and have no close homologs in the S. meliloti genome that might be expected to provide redundant function. Six of the longer ORFs, including SMc00911, were disrupted by cloning a small internal ORF fragment into the plasmid pJH104, conjugating the plasmid into S. meliloti 1021, and selecting for singlecrossover insertion/disruption mutants. (Additional file 2: Table S2 lists primer sequences and disruption fragment sizes and positions.) For the 6 remaining ORFs, 3 that are under 750 bp long (SMc01562, SMc01986 and SMc00135) and 3 that are all in a single operon (SMc01424, SMc01423, and SMc01422), deletion was judged to be a better strategy than disruption. SMc01424, SMc01423, and SMc01422 were all deleted as a single segment from the start codon of SMc01424 to the stop codon of SMc01422. The endpoints of the individual deletions of SMc01562, SMc01986, and SMc00135 were dictated by the position of the most suitable PCR primers. (Additional file 2: Table S2 lists primer sequences and deletion sizes and positions.) Either the disruption or the deletion strategy is expected to result in a strain that does not produce a full-length version of the protein encoded by that ORF. These ORFs and the insertion and/or deletion mutant strains of each are listed and described in Table 2. The resulting mutant strains were then tested for symbiotic proficiency on the host plant alfalfa.

For the initial phenotypic analysis, the ability of the mutants to successfully provide the plants with fixed nitrogen was determined. Alfalfa plants were inoculated with the bacterial mutants and after 5 weeks of growth, the shoot length attained on nitrogen-free medium was compared with plants inoculated with the S. meliloti 1021 wild type as the positive control and uninoculated plants as the negative control. Figure 1 shows the shoot length of alfalfa plants inoculated with wild type S. meliloti 1021 or with disruption mutant strains of the ORFs SMb20360, SMb20431, SMc00911, SMa1344, SMc01266, and SMc03964. Alfalfa plants inoculated with these strains attain a similar average shoot length as that of the wild type, demonstrating that all of these strains are able to form a successful symbiosis with this host plant. Figure 2 presents the same type of assay as Figure 1 for deletion mutants in the ORFs SMc01562, SMc01986, SMc01424-22, SMc00135, and SMa0044. Additional data on the plant assays in Figures 1 and 2 is presented in Table 5 . The number of plants inoculated with each strain, the average number of mature, pink nodules per plant and the average number of white pseudonodules per plant are shown. All of these mutant strains are able to mount a successful symbiosis with the host plant alfalfa.

\section{SMc00911 is the most strongly expressed in the nodule of the conserved ORFS}

To determine if the 13 ORFs analyzed in this study might play a role in symbiosis, despite the fact that they are not strictly required for symbiosis, the expression pattern of each of these ORFs was determined both for bacteria within the nodule and in the free-living state. The SMc00911 ORF is very strongly expressed by bacteria within the nodule (Figure 3B-F), but it expressed at a very low level by free-living bacteria on LBMC plates (Figure 3G). The nodules shown in Figure 3 are expressing $\beta$-glucuronidase (GUS) from a pJH104 plasmid insertion in Smc00911. The nodules shown were stained for $3.75 \mathrm{hr}$. There is strong staining throughout the nodule, with slightly weaker staining at the invasion zone near the distal end of the nodule. The nodule expression of the SMc00911::GUS fusion is much stronger 


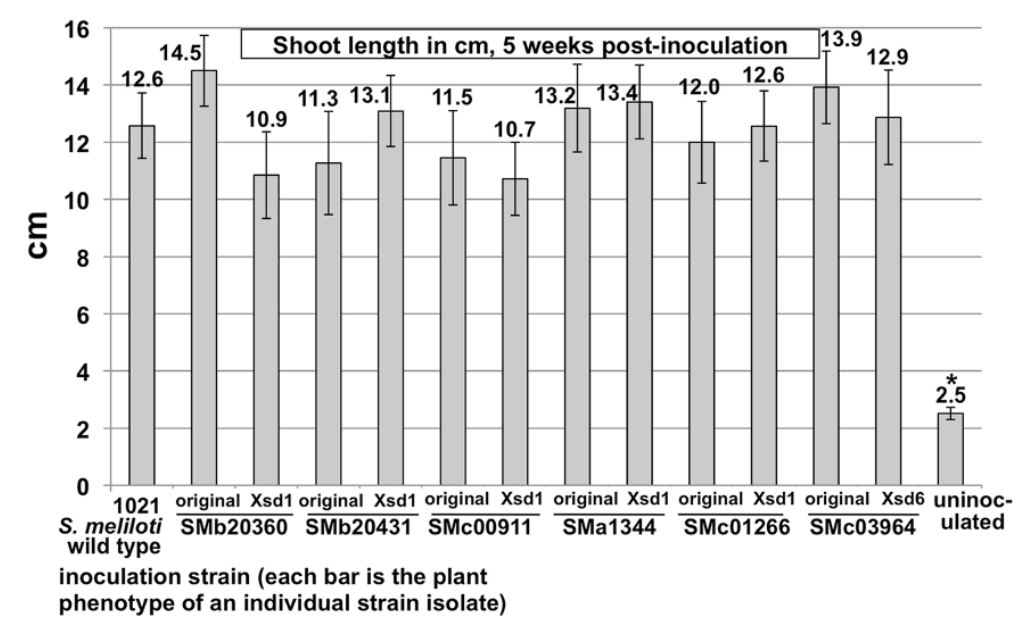

Figure 1 Plant shoot length in cm, 5 weeks after inoculation with insertion mutant strains (mutant strain information is summarized in Table 3). For each of the 6 ORF disruptions, the plant phenotype of the original isolate and that of a phage $\varphi M 12$ transductant of that strain are shown. Mean values are given above graph bars. Error bars represent standard error of the mean. Asterisks indicate samples with mean heights significantly different from the wild type. The number of plants tested and the number of nodules/plant for these assays are presented in Table 4.

than the expression of any of the other fusions tested (see Figure 4 and Table 3). In contrast, SMc00911 is expressed at a very low level by free-living $S$. meliloti carrying the SMc00911::GUS fusion grown on LBMC plates (Figure 3G and Table 3). For comparison, Figure $3 \mathrm{G}$ also shows that a greA::GUS fusion strain of $S$. meliloti constructed with the same reporter insertion plasmid, pJH104, is strongly expressed under these conditions. Table 3 summarizes the expression data for all of the GUS fusion strains.

Two of the other ORFs tested, SMb20360 and Smc00135, are also strongly expressed in nodules (Figure 4B-E, Table 3), and another six, SMc01562, SMc01266, SMc03964 and the three ORFs in the
SMc01424-22 operon are moderately expressed (Figure 4F-M, Table 3). Of these, only SMc00135 is expressed at approximately the same level by bacteria within the nodule and by free-living bacteria (Additional file 4 and Additional file 5 show images of the free-living expression of GUS fusions of all the ORFs tested). However, none of the other ORFs that are expressed in the nodule are expressed as strongly as SMc00911 (Figure 3 and Figure 4). Two of the ORFs, SMa0044 and SMb20431, are expressed at a very low level in the nodule, and no nodule expression was detected for SMc01986 and SMa1334 (Figure 4). Sma0044 has an unusual expression pattern in that it is expressed strongly by free-living bacteria (Additional file 5A), but its

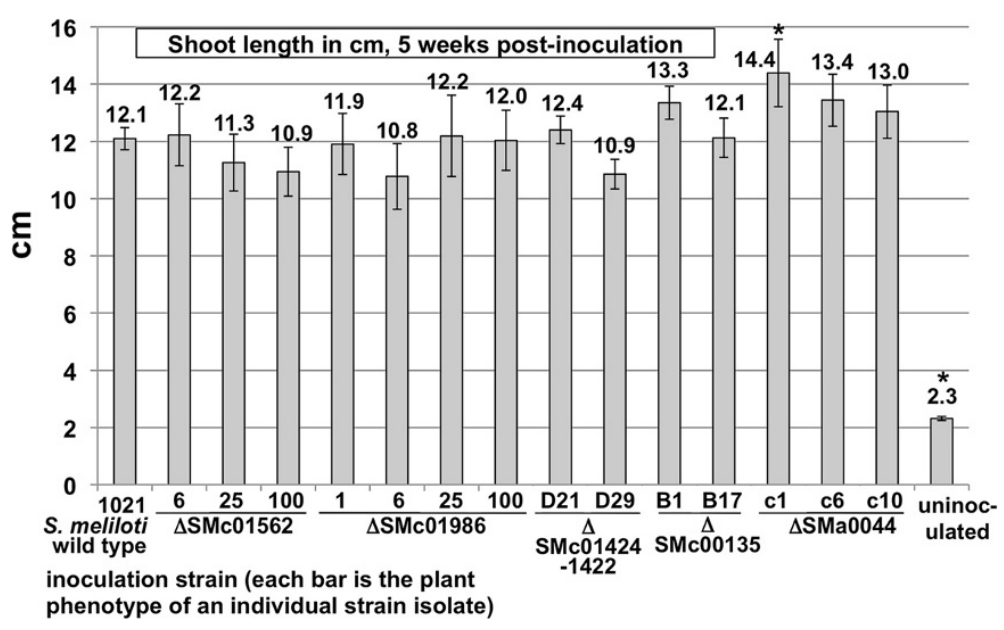

Figure 2 Plant shoot length in $\mathbf{c m}, \mathbf{5}$ weeks after inoculation with deletion mutant strains (summarized in Table 3). For each of the ORF deletions, the plant phenotype of at least two isolates/and or transductants of each strain are shown. Mean values are given above graph bars. Error bars represent standard error of the mean. Asterisks indicate samples with mean heights significantly different from the wild type. The number of plants tested and the number of nodules/plant for these assays are presented in Table 4. 
Table 5 Mean nodule number

\begin{tabular}{|c|c|c|c|c|}
\hline ORF & Strain name & $\begin{array}{l}\text { Number } \\
\text { of alfalfa } \\
\text { plants tested }\end{array}$ & $\begin{array}{l}\text { Mean number } \\
\text { pink nodules/ } \\
\text { plant } \pm \text { std. error }\end{array}$ & $\begin{array}{l}\text { Mean number white } \\
\text { pseudonodules/ } \\
\text { plant } \pm \text { std. error }\end{array}$ \\
\hline N/A & $\begin{array}{l}\text { S. meliloti } 1021 \text { wild type, } \\
\text { data set } 1 \text { (see Figure 1) }\end{array}$ & 9 & $11.9 \pm 1.0$ & $3.2+1.2$ \\
\hline \multirow[t]{2}{*}{ SMb20360 } & SMb20360.original & 8 & $17.4 \pm 2.5$ & $4.5 \pm 1.2$ \\
\hline & SMb20360.Xsd1 & 10 & $14.7 \pm 1.7$ & $4.4 \pm 1.4$ \\
\hline \multirow[t]{2}{*}{ SMb20431 } & SMb20431.original & 11 & $12.8 \pm 1.6$ & $3.0 \pm 0.6$ \\
\hline & SMb20431.Xsd1 & 11 & $13.3 \pm 1.9$ & $3.8 \pm 0.8$ \\
\hline \multirow[t]{2}{*}{ SMc00911 } & SMc00911.original & 11 & $14.3 \pm 2.5$ & $3.3 \pm 0.8$ \\
\hline & SMc00911.Xsd1 & 11 & $15.3 \pm 1.8$ & $3.2 \pm 1.1$ \\
\hline \multirow[t]{2}{*}{ SMa1334 } & SMa1334.original & 10 & $15.7 \pm 2.1$ & $5.7 \pm 0.9$ \\
\hline & SMa1334.Xsd1 & 11 & $16.4 \pm 1.1$ & $3.6 \pm 1.7$ \\
\hline \multirow[t]{2}{*}{ SMc01266 } & SMc01266.original & 11 & $14.4 \pm 2.4$ & $4.2 \pm 0.5$ \\
\hline & SMc01266.Xsd1 & 11 & $17.8 \pm 1.6$ & $4.6 \pm 1.2$ \\
\hline \multirow[t]{2}{*}{ SMc03964 } & SMc03964.original & 11 & $16.3 \pm 1.6$ & $4.2 \pm 0.5$ \\
\hline & SMc03964.Xsd6 & 10 & $15.2 \pm 2.3$ & $4.0 \pm 0.9$ \\
\hline N/A & $\begin{array}{l}\text { uninoculated, data set } 1 \\
\text { (see Figure 1) }\end{array}$ & 5 & 0 & 0 \\
\hline$N / A$ & $\begin{array}{l}\text { S. meliloti } 1021 \text { wild type, } \\
\text { data set } 2 \text { (see Figure 2) }\end{array}$ & 179 & $12.5 \pm 0.5$ & $3.2 \pm 0.3$ \\
\hline \multirow[t]{3}{*}{ SMc01562 } & $\Delta \mathrm{SMC01562.6}$ & 24 & $14.1 \pm 1.3$ & $2.2 \pm 0.4$ \\
\hline & $\Delta \mathrm{SMc01562.25}$ & 25 & $11.6 \pm 1.2$ & $2.5 \pm 0.5$ \\
\hline & $\Delta \mathrm{SMC01562.100}$ & 24 & $11.8 \pm 0.9$ & $2.0 \pm 0.6$ \\
\hline \multirow[t]{4}{*}{ SMc01986 } & $\Delta \mathrm{SMC01986.1}$ & 26 & $18.0 \pm 1.8$ & $4.5 \pm 0.8$ \\
\hline & $\Delta \mathrm{SMC01986.6}$ & 26 & $15.3 \pm 2.1$ & $4.4 \pm 0.8$ \\
\hline & $\Delta \mathrm{SM}$ C01986.25 & 25 & $17.2 \pm 2.3$ & $6.8 \pm 1.1$ \\
\hline & $\Delta \mathrm{SMC} 01986.100$ & 25 & $16.8 \pm 1.8$ & $6.7 \pm 1.0$ \\
\hline \multirow[t]{2}{*}{ SMc01424-22 } & $\Delta \mathrm{SMc01422-24.D21}$ & 110 & $13.1 \pm 0.7$ & $3.7 \pm 0.4$ \\
\hline & $\Delta$ SMc01422-24.D29 & 109 & $11.1 \pm 0.6$ & $3.6 \pm 0.3$ \\
\hline \multirow[t]{2}{*}{ SMc00135 } & $\Delta$ SMc00135.B1 & 81 & $14.0 \pm 0.7$ & $2.8 \pm 0.3$ \\
\hline & $\Delta \mathrm{SMc00135.B17}$ & 76 & $13.5 \pm 0.9$ & $3.3 \pm 0.4$ \\
\hline \multirow[t]{3}{*}{ SMa0044 } & $\Delta \mathrm{SMa0044.c1}$ & 24 & $11.8 \pm 1.3$ & $4.2 \pm 0.6$ \\
\hline & $\Delta \mathrm{SMa0044.c6}$ & 25 & $12.6 \pm 1.2$ & $3.0 \pm 0.8$ \\
\hline & $\Delta \mathrm{SMa0044.c10}$ & 24 & $13.5 \pm 1.2$ & $2.0 \pm 0.5$ \\
\hline N/A & $\begin{array}{l}\text { uninoculated, data set } 2 \\
\text { (see Figure 2) }\end{array}$ & 82 & 0 & $0.1 \pm 0.1$ \\
\hline
\end{tabular}

expression appears to be much reduced in the nodule (Figure 4N-O).

Because of the strong expression of SMc00911 by bacteria in the nodule, the SMc00911 mutant strains were chosen for further study in competition experiments (see below).

An insertion mutant of SMc00911 out-competes the S. meliloti 1021 wild type for nodule occupancy

Many S. meliloti mutant strains that are able to form a successful symbiosis when singly inoculated on host plants are deficient in the ability to successfully compete for nodule occupancy against the wild type strain in a mixed infection [42,51]. Competitive nodulation experiments are likely to be a better approximation of the situation that rhizobial bacteria encounter in the soil, where they may be competing against several different rhizobial strains for host plant invasion and nodule occupancy. The SMc00911 insertion mutant strains were chosen for competition analysis because this ORF is strongly expressed in the nodule and these strains might be expected to be at a competitive disadvantage in the 


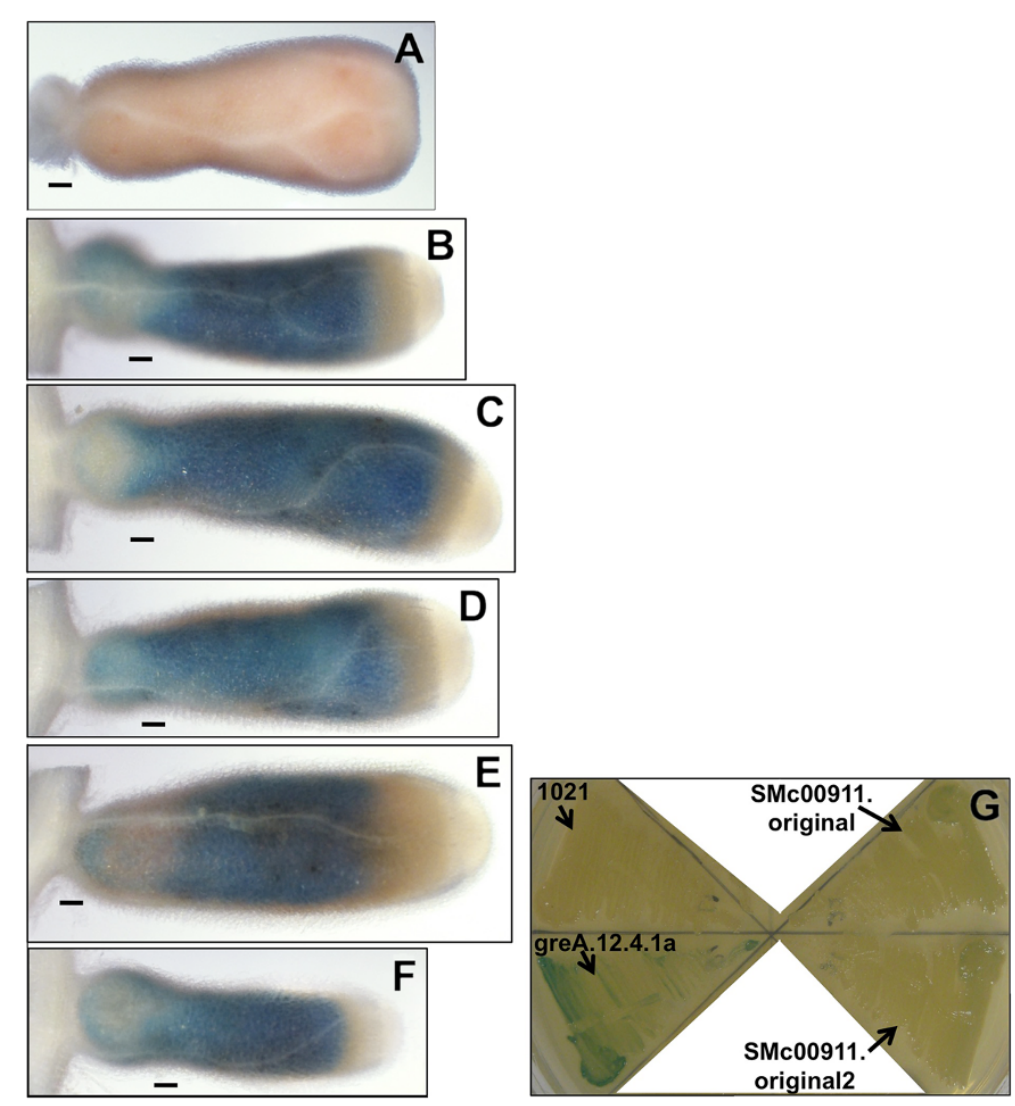

Figure 3 Expression of $\beta$-glucuronidase (GUS)-encoding reporter gene uidA inserted within SMc00911. S. meliloti within alfalfa root nodules (B-F) express GUS inserted in SMc00911 throughout the nodule. Panel A shows an alfalfa nodule invaded by wild type S. meliloti 1021 that does not express GUS (subjected to the same staining procedure as B-F). (Roots in B, C, and D were inoculated with strain SMc00911. Xsd1. Roots in $\mathrm{E}$ and $\mathrm{F}$ were inoculated with strain SMc00911.original.) Nodules were stained for $3.75 \mathrm{hr}$ after 5 weeks of growth post-inoculation. Scale bars correspond to $0.1 \mathrm{~mm}$. Panel G shows SMc00911-controlled GUS expression in S. meliloti grown on solid LBMC medium. Wild type S. meliloti 1021 is shown as a negative control for GUS expression and a strain carrying the same GUS insertion plasmid in the greA gene is shown as a positive control for GUS expression in free-living cells. Strain SMc00911.original and a $\varphi M 12$ transductant of this strain were tested on plants.

absence of the full-length SMc00911 protein. However, in contrast to expectations, the SMc00911 insertion mutant strains strongly out-compete the S. meliloti 1021 wild type strain for nodule occupancy in a mixed 1:1 infection (Table 6). Of the nodules tested from plants inoculated with a 1:1 mixture of 1021 wild type and an SMc00911 insertion mutant, all of the nodules were colonized by either the SMc00911 insertion mutant alone or by a mixture of the mutant and the wild type (Table 6). Less than $22 \%$ of the mixed-inoculum nodules were colonized by 1021 wild type alone. Also, all of the mixed nodules contained a larger proportion of SMc00911 insertion mutant bacteria than 1021 wild type bacteria (Table 6). The recovered bacteria from one of the 8 nodules that had been inoculated with the SMc00911.Xsd1 strain alone included a small number of neomycin-sensitive colonies (Table 6, line 3 ). This suggests that the gene disruption plasmid inserted in the SMc00911 ORF is lost by bacteria in the nodule at a very low rate. Taken together, these competition results suggest that disruption of the SMc00911 ORF actually confers a competitive advantage to $S$. meliloti in the symbiosis with host plants. The SMc00911 ORF is predicted to encode a 275 amino acid protein with a rhodanese-like sulfurtransferase domain from amino acids 7-100 and a chromate-resistance protein domain from amino acids 122-256 [52]. The SMc00911 mutants carry the pJH104-GUS-expression/disruption plasmid inserted at nucleotide position 597 out of 828 total nucleotides, which would result in the production of a truncated protein containing only amino acids 1-199, based on the S. meliloti 1021 genome sequence [53,54]. Thus the SMc00911 insertion mutants are predicted to produce a protein that contains the whole rhodaneselike sulfurtransferase domain, but only a portion of the chromate-resistance protein domain.

In contrast to the SMc00911 insertion mutants, deletion mutants of SMc01562 (which is expressed in the nodule, but at a much lower level than SMc00911 (Figure 4)) are able to compete as effectively as S. meliloti 1021 wild type 

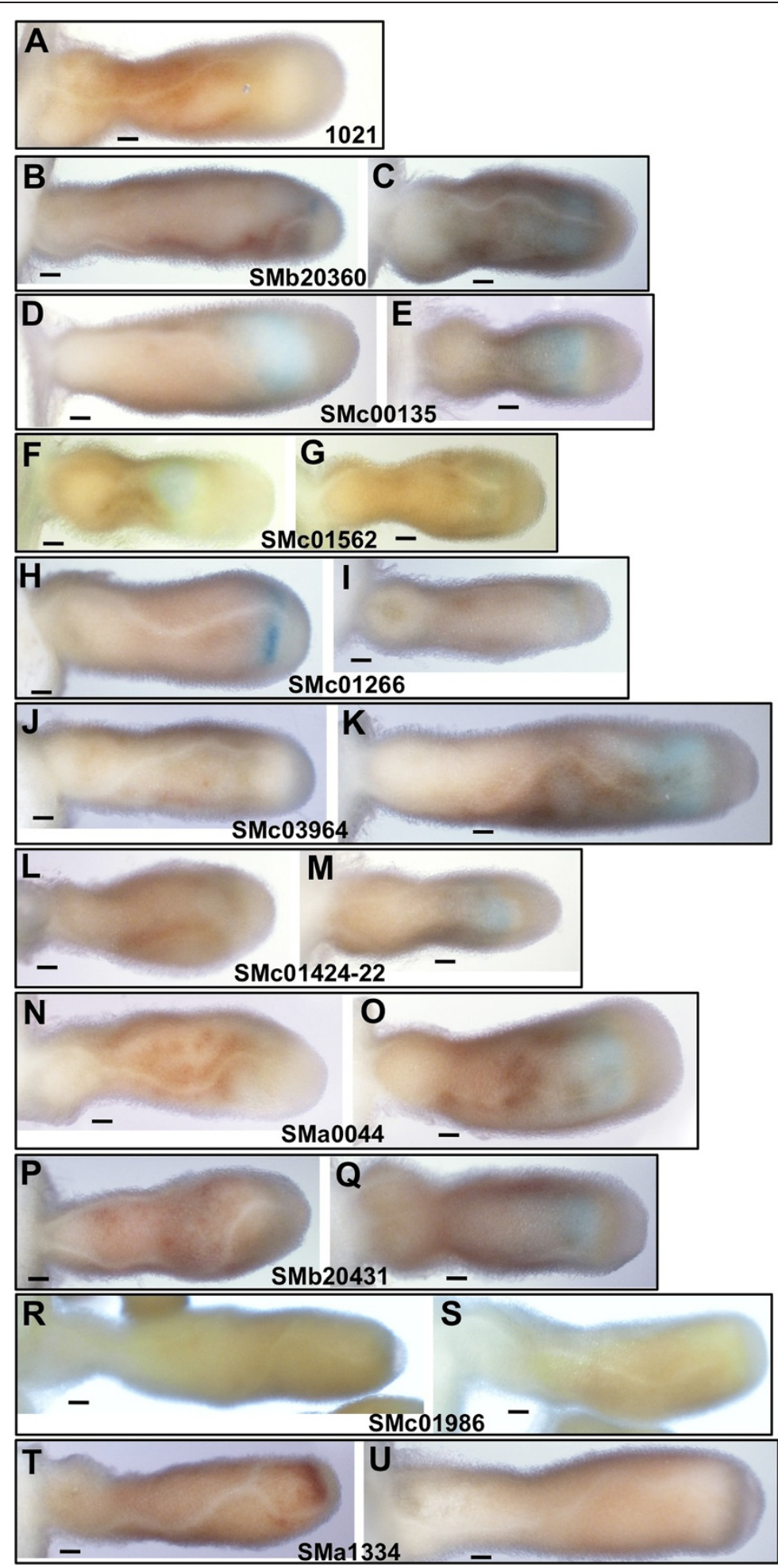

Figure 4 Expression of $\beta$-glucuronidase (GUS)-encoding gene uidA expressed under the control of the promoter elements of the following ORFs: SMb20360 (B and C); SMc00135 (D and E); SMc01562 (F and G); SMc01266 (H and I); SMc03964 (J and K); SMc01424-22 ( $L$ and M); SMa0044 (N and O); SMb20431 (P and Q); SMc01986 (R and S); SMa1334 (T and U). SMb20360 and SMc00135 are strongly expressed in the nodules. (See Table 3 for percentage of nodules with GUS expression and staining times.) SMc01562, SMc01266, SMc03964 and the SMc01424-22 operon are expressed at a moderate level in the nodules. The remaining ORFs are expressed at a very low level in the nodule (or not at all). S. meliloti 1021 wild type is shown in Panel $\mathbf{A}$ as a negative control for GUS expression. Scale bars correspond to $0.1 \mathrm{~mm}$. 
Table 6 SMc00911-disruption strains out-compete S. meliloti 1021 wild type for nodule occupancy

\begin{tabular}{|c|c|c|c|c|c|}
\hline Inoculum & $\begin{array}{l}\text { Number of } \\
\text { nodules } \\
\text { tested }\end{array}$ & $\begin{array}{l}\text { Number of nodules } \\
\text { containing no } \\
\text { neomycin-resistant } \\
\text { bacteria }\end{array}$ & $\begin{array}{l}\text { Number of nodules } \\
\text { containing only } \\
\text { neomycin-resistant } \\
\text { bacteria }\end{array}$ & $\begin{array}{l}\text { Number of nodules } \\
\text { containing a mixture } \\
\text { of neomycin-resistant } \\
\text { and sensitive bacteria }\end{array}$ & $\begin{array}{l}\text { Average percent } \\
\text { of neomycin-resistant } \\
\text { bacteria in mixed } \\
\text { nodules }\end{array}$ \\
\hline $\begin{array}{l}\text { S. meliloti } 1021 \text { wild type } \\
\text { (neomycin-sensitive) }\end{array}$ & 8 & $4=100 \%$ & $0=0 \%$ & $0=0 \%$ & N/A \\
\hline $\begin{array}{l}\text { SMc00911.original } \\
\text { (neomycin-resistant) }\end{array}$ & 16 & $0=0 \%$ & $16=100 \%$ & $0=0 \%$ & N/A \\
\hline $\begin{array}{l}\text { SMc00911.Xsd1 } \\
\text { (neomycin-resistant) }\end{array}$ & 16 & $0=0 \%$ & $15=93.8 \%$ & $1=6.3 \%$ & $95.2 \% \pm 0.00 \%$ \\
\hline SMc00911.original:1021—mixed 1:1 & 32 & $7=21.9 \%$ & $18=56.3 \%$ & $7=21.9 \%$ & $67.4 \% \pm 14.2 \%$ \\
\hline SMc00911.Xsd1:1021—mixed 1:1 & 31 & $2=6.5 \%$ & $21=67.7 \%$ & $8=25.8 \%$ & $76.7 \% \pm 9.8 \%$ \\
\hline
\end{tabular}

* 1-2 nodules/plant were analyzed.

against a competitor assay strain carrying a neomycinresistance marker (data not shown), suggesting that the loss of this protein confers neither a symbiotic disadvantage nor an advantage to $S$. meliloti 1021.

\section{Discussion}

Smc00911, a conserved rhizobial ORF expressed strongly in the nodule

Our comparative genomics screen has identified an S. meliloti 1021 ORF (SMc00911) that is strongly expressed within host plant nodules, but is expressed in the free-living state at a very low level. Surprisingly, disruption of this ORF confers a competitive advantage for nodule occupancy on S. meliloti 1021. Smc00911 is predicted to encode a 275 amino acid protein with overall similarity to SodM-like (superoxide dismutase-like) proteins $[55,56]$. There are 57 "SodM-like proteins" with $>40 \%$ identity to SMc00911 in the NCBI database [56]. SMc00911 contains two distinct, conserved domains: a 94 amino acid domain (amino acids 7-100) similar to the GlpE sufurtransferase/rhodanese homology domain (cd01444), and a 135 amino acid (amino acids 122-256) chromate-resistance-exported protein domain (pfam09828) [52]. The SMc0911 mutant strains constructed in this study are predicted to produce a protein consisting of the first 199 amino acids of the full-length protein plus four amino acids encoded by the multiple cloning site of pJH104, before encountering a stop codon (Melanie Barnett, Stanford University personal communication) $[53,54]$. This truncated protein product would include the entire rhodanese-homology domain and approximately half of the chromate-resistance protein domain. One possibility is that the competitive advantage that the SMc00911-insertion mutant strains have against the 1021 wild type strain is due to the expression of this truncated protein, rather than simply a loss-of-function of the fulllength protein. Even though SMc00911 is annotated as a "SodM-like" protein in the NCBI database [53,54,56], there are only two short segments of similarity (8 amino acids [38\% identity] and 11 amino acids [36\% identity]) with a protein confirmed to be a SodM from Xanthomonas campestris pv. campestris (accession no. p53654) [57]. Thus, since the N-terminal similarity of SMc00911 to the GlpE sufurtransferase/rhodanese homology domain and the C-terminal similarity to the chromateresistance protein domain are both greater than the similarity of this protein to SodM, "SodM-like" may not be the most-appropriate annotation for this ORF. There are two sod ORFs in the S. meliloti 1021 genome, sodB (SMc00043) (SMc02597) and a bacteriocuprein-family sodC (SMc02597) [2,53,54]. An S. meliloti $1021 \operatorname{sodB}$ loss-of-function mutant forms a functional symbiosis with host plants [58], while the symbiotic phenotype of a sodC mutant has not been reported.

\section{Expression of other ahizobial conserved ORFS}

Although they are not required for development of a functional symbiosis by $S$. meliloti 1021, the ORFs SMb20360 and SMc00135 are also strongly expressed in nodules, while SMc01562, SMc01266, SMc03964 and the SMc01424-22 operon are moderately expressed (Figure 4; Table 3). However, the expression of SMc00135 is not specific to the nodule (Figure 4 and Additional file 5). SMb20360 is predicted to encode a protein of the Clp-protease superfamily (COG0740), with specific similarity to ClpP [52]. Polar localization of the ClpXP protease complex within $S$. meliloti cells has been found to be important for $S$. meliloti bacteroid differentiation [59], and it is possible that ClpP proteases play a role in the bacteroid differentiation process. Interestingly, in another study, a signature-tagged mutant in SMb20360 was found to be highly competitive for survival, in the free-living state, in competition experiments under salt- and detergent-stressed conditions [60]. SMc01562 is predicted to encode a member of the GYD-domain containing protein superfamily (COG4274) [52]. No function has been reported for this protein family [56]. SMc01266 is predicted to encode a member of the Von Willebrand factor type A (vFWA) superfamily (cl00057), however proteins containing a vFWA domain 
participate in a wide variety of functions [61]. Expression of SMc01266 has previously been shown to increase in bacteroids [62] (reference Supplemental Dataset 3), and during phosphate stress [63]. Smc03964 is predicted to possess a twin-arginine export signal [64], and to encode a member of the metallophosphatase superfamily (cl13995), a group of phosphatases with diverse functions [52]. ORFs SMc01424, SMc01423, and SMc01422 appear to be part of a single operon and they encode, respectively, a predicted nitrile hydratase alpha subunit protein, a nitrile hydratase beta subunit protein, and a nitrile hydratase activator protein [53,54]. Nitrile hydratases function in the degradation of xenobiotic compounds, but they are also involved in tryptophan metabolism, specifically in the conversion of 3-indoleacetonitrile to indole-3-acetamide, which is a precursor of the plant hormone auxin $[65,66]$. SMa0044 has an unusual expression pattern in that it is expressed at a very low level in approximately half of the nodules tested (Table 3; Figure 4), but is expressed quite strongly by free-living $S$. meliloti on LBMC medium (Additional file 5). SMa0044 is predicted to encode a member of the DUF2277 superfamily, which is has no known function [52].

\section{Conclusions}

The goal of this study was to identify S. meliloti 1021 ORFs involved in host plant nodulation and nitrogen fixation. The comparative genomics method we employed was able to rediscover 19 ORFs that have previously been shown to be important for nodulation and/or nitrogen fixation. The earlier studies that identified these genes, in most cases, employed the classical bacterial genetic techniques of transposon mutagenesis, followed by strain isolation and phenotypic screening $[11,67][68]$. Our study identified 9 additional S. meliloti ORFs (out of the 13 we analyzed) that we have shown are expressed primarily in host plant nodules. However none of these newly identified ORFs were required for development of a functional symbiosis under the conditions we tested. Our results suggest that the accumulated transposon screens for essential S. meliloti nodulation/nitrogen fixation genes may be nearing saturation. However, the comparative genomics method described above might be very effective for identifying factors involved in the production of a phenotype common to a group of bacterial species that have not yet been studied by classical transposon mutagenesis screens.

\section{Additional files}

Additional file 1: Table S1. Joint Genome Institute, Integrated Microbial Genomes Phylogenetic Profile search data on single genes.

Additional file 2: Table S2. Primers used to amplify S. meliloti 1021

fragments for construction of insertion mutants and deletion mutants.
Additional file 3: Table S3. Gene list of 139 ORFs compiled from search data in Additional file 1: Table S1.

Additional file 4: Free-living expression of $\beta$-glucuronidase (GUS) under the control of the promoters of the following ORFs: A) clockwise from lower left-SMc01266; greA (positive control for GUS expression); S. meliloti 1021 wild type (negative control for GUS expression); SMb20431; SMa1334. (The cropped plate wedges in panel A are all from the same plate.) B) clockwise from lower right-SMc01986; SMc01562; SMc03964; greA; S. meliloti 1021; a second streak of SMc03964. C) (clockwise from left) greA; S. meliloti 1021; SMb20360 (two separate strains). Specific strain names are shown in the photo labels. The growth medium is LBMC, with streptomycin $500 \mathrm{ug} / \mathrm{mL}$.

Additional file 5: Free-living expression of $\beta$-glucuronidase (GUS) under the control of the promoters of the following ORFs: A) SMa0044. Multiple isolates of the SMa0044::GUS fusions are shown in comparison with greA (positive control for GUS expression) and S. meliloti 1021 wild type (negative control for GUS expression). B) SMc00135. Multiple isolates of the SMC00135::GUS fusions are shown in comparison with greA and S. meliloti 1021 wild type. C) the SMc01424-01422 operon. Multiple isolates of the SMc01424-01422: GUS fusions are shown in comparison with greA and S. meliloti 1021 wild type. The growth medium is LBMC, with streptomycin $500 \mathrm{ug} / \mathrm{mL}$. GUS expression strains that were tested for nodule expression are denoted with an asterisk and are described in Tables 3 and 4.

\section{Competing interests}

The authors declare that they have no competing interests.

\section{Authors' contributions}

$\mathrm{KMJ}$ conceived of the study, performed the genome comparisons, designed experiments, constructed bacterial mutant strains, performed experiments, interpreted results and drafted the manuscript. CQ designed experiments, constructed bacterial mutant strains, performed experiments, interpreted results and helped draft the manuscript. BKW constructed bacterial mutant strains, performed experiments, and helped draft the manuscript. OMD, JS, TEB, and MRL constructed bacterial mutant strains and performed experiments. All authors read and approved the final manuscript.

\section{Acknowledgments}

The authors wish to thank Sharon Long, Melanie Barnett, and Jeanne Harris for plasmid pJH104; Graham Walker for plasmid pK19mobsac; and Michiko E. Taga, Penny J. Beuning and George W. Bates for critical reading of the manuscript.

This work was funded by start-up funds provided to KMJ by Florida State University.

\section{Author details}

'Department of Biological Science, Florida State University, Biology Unit I, 230A, 89 Chieftain Way, Tallahassee, FL 32306-4370, USA. 2Present address: Department of Psychology, Brooklyn College, Brooklyn, NY, USA. ${ }^{3}$ Present address: Arthrex Orthopaedic Products, Jacksonville, FL, USA.

Received: 24 January 2012 Accepted: 4 May 2012

Published: 15 May 2012

\section{References}

1. Jones KM, Kobayashi H, Davies BW, Taga ME, Walker GC: How rhizobial symbionts invade plants: the Sinorhizobium-Medicago model. Nat Rev Microbiol 2007, 5(8):619-633.

2. Gibson KE, Kobayashi H, Walker GC: Molecular determinants of a symbiotic chronic infection. Annu Rev Genet 2008, 42:413-441.

3. Huang W: Data Sets: U.S. Fertilizer Use and Price. In. Edited by Service UER: usda.gov; 2008.

4. Peters NK, Frost JW, Long SR: A plant flavone, luteolin, induces expression of Rhizobium meliloti nodulation genes. Science 1986, 233:977-980.

5. Gage DJ: Infection and invasion of roots by symbiotic, nitrogen-fixing rhizobia during nodulation of temperate legumes. Microbiol Mol Biol Rev 2004, 68(2):280-300.

6. Oldroyd GE, Downie JA: Nuclear calcium changes at the core of symbiosis signalling. Curr Opin Plant Biol 2006, 9(4):351-357. 
7. Timmers AC, Auriac MC, Truchet G: Refined analysis of early symbiotic steps of the Rhizobium-Medicago interaction in relationship with microtubular cytoskeleton rearrangements. Development 1999, 126(16):3617-3628.

8. Catalano CM, Czymmek KJ, Gann JG, Sherrier DJ: Medicago truncatula syntaxin SYP132 defines the symbiosome membrane and infection droplet membrane in root nodules. Planta 2007, 255(3):541-550.

9. Mergaert P, Uchiumi T, Alunni B, Evanno G, Cheron A, Catrice O, Mausset $A E$, Barloy-Hubler F, Galibert F, Kondorosi A, et al: Eukaryotic control on bacterial cell cycle and differentiation in the Rhizobium-legume symbiosis. Proc Natl Acad Sci U S A 2006, 103(13):5230-5235.

10. Prell J, Poole P: Metabolic changes of rhizobia in legume nodules. Trends Microbiol 2006, 14(4):161-168.

11. Ruvkun GB, Sundaresan V, Ausubel FM: Directed transposon Tn5 mutagenesis and complementation analysis of Rhizobium meliloti symbiotic nitrogen fixation genes. Cell 1982, 29(2):551-559.

12. Poole P, Allaway D: Carbon and nitrogen metabolism in Rhizobium. Adv Microb Physiol 2000, 43:117-163.

13. Hirsch AM, Smith CA: Effects of Rhizobium meliloti nif and fix mutants on alfalfa root nodule development. J Bacteriol 1987, 169:1137-1146.

14. Masson-Boivin C, Giraud E, Perret X, Batut J: Establishing nitrogen-fixing symbiosis with legumes: how many rhizobium recipes? Trends Microbiol 2009, 17(10):458-466.

15. Meade HM, Long SR, Ruvkun GB, Brown SE, Ausubel FM: Physical and genetic characterization of symbiotic and auxotrophic mutants of Rhizobium meliloti induced by transposon Tn5 mutagenesis. J Bacteriol 1982, 149(1):114-122.

16. Earl CD, Ronson CW, Ausubel FM: Genetic and structural analysis of the Rhizobium meliloti fixA, fixB, fixC, and fixX genes. J Bacteriol 1987, 169(3):1127-1136.

17. Preisig $\mathrm{O}$, Anthamatten $\mathrm{D}$, Hennecke $\mathrm{H}$ : Genes for a microaerobically induced oxidase complex in Bradyrhizobium japonicum are essential for a nitrogen-fixing endosymbiosis. Proc Natl Acad Sci U S A 1993, 90(8):3309-3313.

18. Arunothayanan $H$, Nomura $M$, Hamaguchi $R$, Itakura M, Minamisawa $K$, Tajima S: Copper metallochaperones are required for the assembly of bacteroid cytochrome coxidase which is functioning for nitrogen fixation in soybean nodules. Plant Cell Physiol 2010, 51(7):1242-1246

19. Rubio LM, Ludden PW: Biosynthesis of the iron-molybdenum cofactor of nitrogenase. Annu Rev Microbio/ 2008, 62:93-111.

20. Becker A, Berges H, Krol E, Bruand C, Ruberg S, Capela D, Lauber E, Meilhoc $E$, Ampe F, de Bruijn FJ, et al: Global changes in gene expression in Sinorhizobium meliloti 1021 under microoxic and symbiotic conditions. Mol Plant Microbe Interact 2004, 17(3):292-303.

21. David M, Daveran ML, Batut J, Dedieu A, Domergue O, Ghai J, Hertig C, Boistard P, Kahn D: Cascade regulation of nif gene expression in Rhizobium meliloti. Cell 1988, 54(5):671-683.

22. Wong PP, Burris RH: Nature of oxygen inhibition of nitrogenase from Azotobacter vinelandii. Proc Natl Acad Sci U S A 1972, 69(3):672-675.

23. Dreyfus BL, Elmerich C, Dommergues YR: Free-living Rhizobium strain able to grow on $\mathrm{n}(2)$ as the sole nitrogen source. Appl Environ Microbiol 1983, 45(2):711-713

24. Van de Velde W, Zehirov G, Szatmari A, Debreczeny M, Ishihara H, Kevei Z, Farkas A, Mikulass K, Nagy A, Tiricz H, et al: Plant peptides govern terminal differentiation of bacteria in symbiosis. Science 2010, 327(5969):1122-1126.

25. Driscoll BT, Finan TM: $\mathrm{NAD}^{+}$-dependent malic enzyme of Rhizobium meliloti is required for symbiotic nitrogen fixation. Mol Micro 1993, 7(6):865-873.

26. Driscoll BT, Finan TM: Properties of NAD(+)- and NADP(+)-dependent malic enzymes of Rhizobium (Sinorhizobium) meliloti and differential expression of their genes in nitrogen-fixing bacteroids. Microbiology 1997, 143(Pt 2):489-498.

27. Rogers A, Ainsworth EA, Leakey AD: Will elevated carbon dioxide concentration amplify the benefits of nitrogen fixation in legumes? Plant Physiol 2009, 151(3):1009-1016.

28. Rasko DA, Rosovitz MJ, Myers GS, Mongodin EF, Fricke WF, Gajer P, Crabtree J, Sebaihia M, Thomson NR, Chaudhuri R, et al: The pangenome structure of Escherichia coli: comparative genomic analysis of E. coli commensal and pathogenic isolates. J Bacteriol 2008, 190(20):6881-6893.
29. de Crecy-Lagard V, El Yacoubi B, de la Garza RD, Noiriel A, Hanson AD: Comparative genomics of bacterial and plant folate synthesis and salvage: predictions and validations. BMC Genomics 2007, 8:245.

30. Goodner B, Hinkle G, Gattung S, Miller N, Blanchard M, Qurollo B, Goldman BS, Cao Y, Askenazi M, Halling C, et al: Genome sequence of the plant pathogen and biotechnology agent Agrobacterium tumefaciens C58. Science 2001, 294(5550):2323-2328.

31. Wood DW, Setubal JC, Kaul R, Monks DE, Kitajima JP, Okura VK, Zhou Y, Chen L, Wood GE, Almeida NF Jr, et al: The genome of the natural genetic engineer Agrobacterium tumefaciens C58. Science 2001, 294(5550):2317-2323.

32. Nierman WC, Feldblyum TV, Laub MT, Paulsen IT, Nelson KE, Eisen JA, Heidelberg JF, Alley MR, Ohta N, Maddock JR, et al: Complete genome sequence of Caulobacter crescentus. Proc Natl Acad Sci U S A 2001, 98(7):4136-4141.

33. Mannisto MK, Tiirola MA, Salkinoja-Salonen MS, Kulomaa MS, Puhakka JA: Diversity of chlorophenol-degrading bacteria isolated from contaminated boreal groundwater. Arch Microbio/ 1999, 171(3):189-197.

34. Genome Project: Caulobacter sp. K31 [http://img.jgi.doe.gov/cgi-bin/pub/ main.cgi?section = TaxonDetail\&page = taxonDetail\&taxon_oid $=641522612$ ]

35. Kaneko T, Nakamura Y, Sato S, Minamisawa K, Uchiumi T, Sasamoto S, Watanabe A, Idesawa K, Iriguchi M, Kawashima K, et al: Complete genomic sequence of nitrogen-fixing symbiotic bacterium Bradyrhizobium japonicum USDA110. DNA Res 2002, 9(6):189-197.

36. Kaneko T, Nakamura Y, Sato S, Asamizu E, Kato T, Sasamoto S, Watanabe A, Idesawa K, Ishikawa A, Kawashima K, et al: Complete genome structure of the nitrogen-fixing symbiotic bacterium Mesorhizobium loti (supplement). DNA Res 2000, 7(6):381-406.

37. Gonzalez V, Santamaria RI, Bustos P, Hernandez-Gonzalez I, Medrano-Soto A, Moreno-Hagelsieb G, Janga SC, Ramirez MA, Jimenez-Jacinto V,

Collado-Vides J, et al: The partitioned Rhizobium etli genome: genetic and metabolic redundancy in seven interacting replicons. Proc Natl Acad Sci U S A 2006, 103(10):3834-3839.

38. Young JP, Crossman LC, Johnston AW, Thomson NR, Ghazoui ZF, Hull KH, Wexler M, Curson AR, Todd JD, Poole PS, et al: The genome of Rhizobium leguminosarum has recognizable core and accessory components. Genome Biol 2006, 7(4):R34.

39. Reeve WG, Chain P, O'Hara G, Ardley J, Nandesena K, Brau L, Tiwari RP, Malfatti S, Kiss H, Lapidus A, et al: Complete genome sequence of the Medicago microsymbiont Ensifer (Sinorhizobium) medicae strain WSM419. Standards in Genomic Sciences 2010, 2:77-86.

40. Sambrook J, Fritsch EF, Maniatis T: Molecular cloning: a laboratory manual. 2nd edition. Cold Spring Harbor, N. Y: Cold Spring Harbor Laboratory Press; 1982.

41. Schäfer A, Tauch A, Jäger W, Kalinowski J, Thierbach G, Pühler A: Small mobilizable multi-purpose cloning vectors derived from the Escherichia coli plasmids pK18 and pK19: selection of defined deletions in the chromosome of Corynebacterium glutamicum. Gene 1994, 145:69-73.

42. Ferguson GP, Datta A, Carlson RW, Walker GC: Importance of unusually modified lipid A in Sinorhizobium stress resistance and legume symbiosis. Mol Microbiol 2005, 56(1):68-80.

43. Glazebrook J, Walker GC: Genetic techniques in Rhizobium meliloti. Methods Enzymol 1991, 204:398-418.

44. Finan TM, Hartweig E, LeMieux K, Bergman K, Walker GC, Signer ER: General transduction in Rhizobium meliloti. J Bacteriol 1984, 159(1):120-124.

45. Leigh JA, Signer ER, Walker GC: Exopolysaccharide-deficient mutants of Rhizobium meliloti that form ineffective nodules. Proc Natl Acad Sci USA 1985, 82:6231-6235.

46. Vincent JM: A Manual for the Practical Study of the Root-Nodule Bacteria. Oxford: Blackwell; 1970

47. Jefferson RA, Kavanagh TA, Bevan MW: GUS fusions: beta-glucuronidase as a sensitive and versatile gene fusion marker in higher plants. EMBO J 1987, 6(13):3901-3907.

48. Markowitz VM, Ivanova NN, Szeto E, Palaniappan K, Chu K, Dalevi D, Chen IM, Grechkin Y, Dubchak I, Anderson I, et al: IMG/M: a data management and analysis system for metagenomes. Nucleic Acids Res 2008, 36(Database issue):D534-D538.

49. Prell J, White JP, Bourdes A, Bunnewell S, Bongaerts RJ, Poole PS: Legumes regulate Rhizobium bacteroid development and persistence by the supply of branched-chain amino acids. Proc Natl Acad Sci U S A 2009, 106(30):12477-12482. 
50. Tellez-Sosa J, Soberon N, Vega-Segura A, Torres-Marquez ME, Cevallos MA: The Rhizobium etli cyaC product: characterization of a novel adenylate cyclase class. J Bacterio/ 2002, 184(13):3560-3568.

51. Campbell GR, Sharypova LA, Scheidle H, Jones KM, Niehaus K, Becker A, Walker GC: Striking complexity of lipopolysaccharide defects in a collection of Sinorhizobium meliloti mutants. J Bacterio/ 2003, 185(13):3853-3862.

52. Marchler-Bauer A, Lu S, Anderson JB, Chitsaz F, Derbyshire MK, DeWeeseScott C, Fong JH, Geer LY, Geer RC, Gonzales NR, et al: CDD: a Conserved Domain Database for the functional annotation of proteins. Nucleic Acids Res 2011, 39(Database issue):D225-D229.

53. Galibert F, Finan TM, Long SR, Pühler A, Abola P, Ampe F, Barloy-Hubler F, Barnett MJ, Becker A, Boistard P, et al: The composite genome of the legume symbiont Sinorhizobium meliloti. Science 2001, 293(5530):668-672.

54. Becker A, Barnett MJ, Capela D, Dondrup M, Kamp PB, Krol E, Linke B, Ruberg S, Runte K, Schroeder BK, et al: A portal for rhizobial genomes: RhizoGATE integrates a Sinorhizobium meliloti genome annotation update with postgenome data. J Biotechnol 2009, 140(1-2):45-50.

55. Barloy-Hubler F, Cheron A, Hellegouarch A, Galibert F: Smc01944, a secreted peroxidase induced by oxidative stresses in Sinorhizobium meliloti 1021. Microbiology 2004, 150(Pt 3):657-664.

56. Altschul SF, Madden TL, Schaffer AA, Zhang J, Zhang Z, Miller W, Lipman DJ: Gapped BLAST and PSI-BLAST: a new generation of protein database search programs. Nucleic Acids Res 1997, 25(17):3389-3402.

57. Watt SA, Tellstrom V, Patschkowski T, Niehaus K: Identification of the bacterial superoxide dismutase (SodM) as plant-inducible elicitor of an oxidative burst reaction in tobacco cell suspension cultures. J Biotechnol 2006, 126(1):78-86.

58. Davies BW, Walker GC: Disruption of sitA Compromises Sinorhizobium meliloti for Manganese Uptake Required for Protection Against Oxidative Stress. J Bacteriol 2006, 189(5):2101-2109.

59. Kobayashi H, De Nisco NJ, Chien P, Simmons LA, Walker GC: Sinorhizobium meliloti CpdR1 is critical for co-ordinating cell cycle progression and the symbiotic chronic infection. Mol Microbiol 2009, 73(4):586-600.

60. Pobigaylo N, Wetter D, Szymczak S, Schiller U, Kurtz S, Meyer F, Nattkemper TW, Becker A: Construction of a large signature-tagged mini-Tn5 transposon library and its application to mutagenesis of Sinorhizobium meliloti. Appl Environ Microbiol 2006, 72(6):4329-4337.

61. Colombatti A, Bonaldo P, Doliana R: Type A modules: interacting domains found in several non-fibrillar collagens and in other extracellular matrix proteins. Matrix 1993, 13(4):297-306.

62. Barnett MJ, Toman CJ, Fisher RF, Long SR: A dual-genome Symbiosis Chip for coordinate study of signal exchange and development in a prokaryote-host interaction. Proc Natl Acad Sci U S A 2004, 101(47):16636-16641. Epub 12004 Nov 16612.

63. Krol E, Becker A: Global transcriptional analysis of the phosphate starvation response in Sinorhizobium meliloti strains 1021 and 2011. Mol Genet Genomics 2004, 272(1):1-17. Epub 2004 Jun 2023.

64. Meloni S, Rey L, Sidler S, Imperial J, Ruiz-Argueso T, Palacios JM: The twin-arginine translocation (Tat) system is essential for Rhizobium-legume symbiosis. Mol Microbio/ 2003, 48(5):1195-1207.

65. Kobayashi M, Suzuki T, Fujita T, Masuda M, Shimizu S: Occurrence of enzymes involved in biosynthesis of indole-3-acetic acid from indole-3-acetonitrile in plant-associated bacteria, Agrobacterium and Rhizobium. Proc Natl Acad Sci U S A 1995, 92(3):714-718.

66. Spaepen S, Vanderleyden J, Remans R: Indole-3-acetic acid in microbial and microorganism-plant signaling. FEMS Microbiol Rev 2007, 31(4):425-448.

67. Buikema WJ, Long SR, Brown SE, van den Bos RC, Earl C, Ausubel FM: Physical and genetic characterization of Rhizobium meliloti symbiotic mutants. J Mol App/ Genet 1983, 2(3):249-260.

68. Egelhoff $\Pi$, Long SR: Rhizobium meliloti nodulation genes: identification of nodDABC gene products, purification of nodA protein, and expression of nodA in Rhizobium meliloti. J Bacteriol 1985, 164(2):591-599.

doi:10.1186/1471-2180-12-74

Cite this article as: Queiroux et al.: A comparative genomics screen identifies a Sinorhizobium meliloti 1021 sodM-like gene strongly expressed within host plant nodules. BMC Microbiology 2012 12:74.

\section{Submit your next manuscript to BioMed Central and take full advantage of:}

- Convenient online submission

- Thorough peer review

- No space constraints or color figure charges

- Immediate publication on acceptance

- Inclusion in PubMed, CAS, Scopus and Google Scholar

- Research which is freely available for redistribution

Submit your manuscript at www.biomedcentral.com/submit

() Biomed Central 